\title{
Language Disorders in Alzheimer's Disease and Phatic Function
}

\author{
Philippe Thomas', Cyril Hazif-Thomas ${ }^{2}$ \\ ${ }^{1}$ Centre de Recherches Sémiotiques (CeReS, EA 3648), Université de Limoges, Limoges, France \\ ${ }^{2}$ Department of Psychiatry for the Elderly (EA 4686), Brest, France \\ Email: philippe.thomas@etu.unilim.fr
}

Received 19 April 2016; accepted 2 July 2016; published 5 July 2016

Copyright (C) 2016 by authors and Scientific Research Publishing Inc.

This work is licensed under the Creative Commons Attribution International License (CC BY).

http://creativecommons.org/licenses/by/4.0/

(c) $\underset{\mathrm{EY}}{\mathrm{i}}$ Open Access

\begin{abstract}
Alzheimer's disease is accompanied by progressive aphasia which intensifies the cognitive problems. The quality of the care given to the patient influences, however, the evolution of his language difficulties. The way the vulnerable person is aided, and the extent to which his efforts to make himself understood by his human environment are validated, contribute to preventing the development of a feeling of failure, a tendency to give up, and retrogressive tendencies. Repetition of interpersonal disqualifiers, care dispensed neglecting inter subjectivity, to the contrary encourages the patient to limit contact with his environment and so precipitate his language difficulties. Aphasia is thus linked to the insufficiency of human communication. The consequences of this disorder can be limited by taking into account the phatic language function to keep communication channels open. The human relationship is an encounter, an act of mutual identity-giving. Alzheimer-patient identity break-down is linked to cognitive troubles and to the failure of patients' relationship attempts.
\end{abstract}

\section{Keywords}

Alzheimer Disease, Aphasia, Semiotics, Language Function

\section{Introduction}

Alzheimer is a neurodegenerative disease with frequency of occurrence increasing with the advance of old age [1]-[5]. If progressively installed memory problems here figure right up front, other neuro-psycho-cognitive disorders are also associated, with language problems that can go as far as aphasia. The disease is accompanied by deterioration of understanding, speech, writing, reading... [6]. Language disorders figure amongst the most significant symptoms of Alzheimer's disease [7] [8]. Initially slight, they increase over time corresponding to fore- 
seeable stages. Memory disorders interact with language/speech features [9]. A realisation of the importance of these two components would help to better prepare for the consequences on the patient's social life.

\section{Language Functions According to Jacobson}

According to Jakobson [10], every verbal communication involves six factors (Figure 1):

1) A context in which the message is set;

2) A sender who formulates the message;

3) A receiver;

4) A channel between Sender and Receiver consisting of a call and inter-subject communication;

5) Codes enabling inter-comprehension;

6) A message.

Six language functions correspond to these factors. To "context" corresponds the referential function a); to "sender" corresponds a function of desire for sharing, here called "emotive" b); to "receiver" corresponds the function of desire for understanding and interpretation, the conative function c); the desire of contact and maintaining an interpersonal link is the phatic function d); the phatic function is the only factor in which a person deprived of the use of language can enter into relation with another. The codes understood by both sender and receiver define the metalinguistic function e); lastly, the effort made by the senderto make the message agreeable, accessible, or, at least, aesthetic, is the poetic function f). The musicality of the language, the tone and pitch of a voice, are important in Alzheimer's when words are no longer understood. The prosody of the words used becomes more important than the actual message conveyed by them.

\section{The Language of a Patient with Dementia}

Studies of the language used by the demented have shown at least relative and temporary maintenance of its structural features [11]-[13]. The accent is often placed on correct preservation of structural features such as phonology, syntax, contrasting with the performance of the patient "speaking dementedly". The capacity of being able to formulate and express distress to a world that escapes conscience (the conscience of togetherness as well as self-consciousness) is a source of suffering for the ill person and his family [14]-[16]. Understanding the mechanisms of language thus comes into question when interpreting the meaning of the ill person's behavioural symptoms.

Language problems and mutual incomprehension are often part of the hidden causes that can sometimes lead formal or informal carers (family carers or near ones) into stressful situations: psychological or psychiatric problems within the family, non-admitted or covered-up family disputes, financial problems linked to mistakes made by the ill person, unfortunately also certain persons' tactlessness...

Context

(Referential) (a)

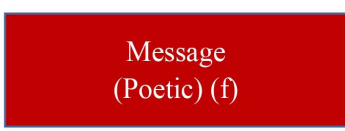

Receiver

(Conative) (c)

Channel

(Phatique) (d)

Codes

(Métalinguistic) (e)

Figure 1. Jakobson's six languagefunctions. 
Conflict between family and carers in homes for dependant old persons or at their private homes is a cause of many complications. This can be far from harmless for the patients themselves and cause them to develop depression and behavioural disorders.

It can be the source of stress, distress, exhaustion in the carer or helper teams, going as far as depression and burnout [17]. Stress and depression as satellites of the difficulty in finding meaningfulness in a relationship thereby spare neither the patient, the formal carers, nor the members of the family. What is at stake with these frequent problems is therefore of importance. [18].

\section{Social Deafferentation and Language Disorders}

Language degradation occurs progressively in Alzheimer's, gradually impeding verbal communication and thereby causing the elderly patient's isolation. It is not just a simple question of aphasia [19]. Words are in fact lost or misused. But, at least at the beginning of the disease, syntaxical structures are preserved without loss of coherency.

Language, little by little, loses its significance as a sharing in an acceptable meaningfulness if not simply accepted for what it is: the need to carry on building the story of ones life. The quality of care given to the ill person modulates the evolution of language difficulties for seniors with dementia. The way they are listened to, and their efforts to make themselves understood are validated prevents the development of the feeling of failure, a tendency to give up and regressive evolution. Repetition of interpersonal disqualifications, care-work carried out neglecting inter-subjective relations, to the contrary, encourage the ill person to restrict his environmental involvement, so precipitating his language difficulties. Aphasia is thus partially connected with insufficient human communication. The consequences of the problem can also be limited by incorporating the phatic function in maintaining the communication channels open. Carers are aware of this difficult apprehension which particularly calls for individualised back-up especially by resorting to the lending of words.

\section{Psychotic and Regressive Risks}

Not all the social deafferentation of the elderly person is to be put down to the disease. Isolated, sometimes in the midst of a group of seniors with dementia, in the presence of carer staff overworked in their job, the demented person repeatedly and vainly seeks to communicate, but doesn't have either the response or the words for it (Figure 2). Formal and largely uninformative, intersubjective relational needs are stable and, so, seem to reduce down to a phatic function, with the demented person using common-places, repetitive gestures and even cries or noises to attract a minimum of attention. These are the needs that, at a distance from the "regressive capacity", dominate a fall-back segment in which "natural help" is still dispensable. By their behaviour, the ill persons still make signs "in the real" to the carers [20].

When this phatic function itself is no longer efficient, for instance, when the ill person remains often isolated in a nursing home, regression or psychotic disorders then become a major risk. Both mark an incapacity to manage, then, refusal of reality (Figure 3). Currently used nosographic frameworks (CIM-10 and DSM V) are insufficient in explaining the disorders apparent in elderly patients, as is illustrated by the very singular syndrome of the "late companion or partner" [21]. It corresponds to the last resource to create a virtual partner. Psychotic syndrome or regression? Only a return to the psycho-pathological approach by the carers in all its dimensions can throw light on the clinical scene, all the more so in presence of heterogeneous pathologies, marked in their behavioural patterns by a clinical-organic divergence.

Synchronic or diachronic functional analysis of a symptom is insufficient to establish a sense or direction in the patient's history. Even defensive mechanisms escape the structure. Stress and anguish limit the coping defences of the ill person, now exposed to the psychotic register.

Delirium can indeed also be an attempt by the subject to interpret his environment. The frequent association of dementia, confusion and troubles of humour or of an emotional type explain the high frequency of delirious reactions, from that consisting of denying somebody's death, to that of longevity.

In psychiatrics for the elderly, it has to be said that delirium is frequent, with no obvious link to a pre-morbid personality but linked significantly to family and social isolation with somatic pathologies favouring regression, deafferentation of the senses, stressful events and depression.

When actual words fail them, the ill have nothing else to turn to than repetitive, stereotyped behaviour difficult for those around them to understand. Beyond the words of language, the human relationship is an encounter, 


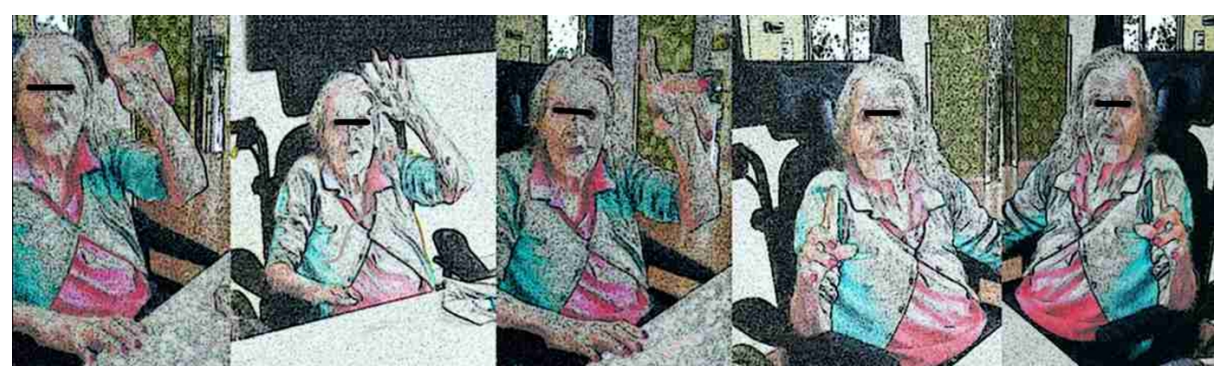

Figure 2. The phatic function in Alzheimer's disease.

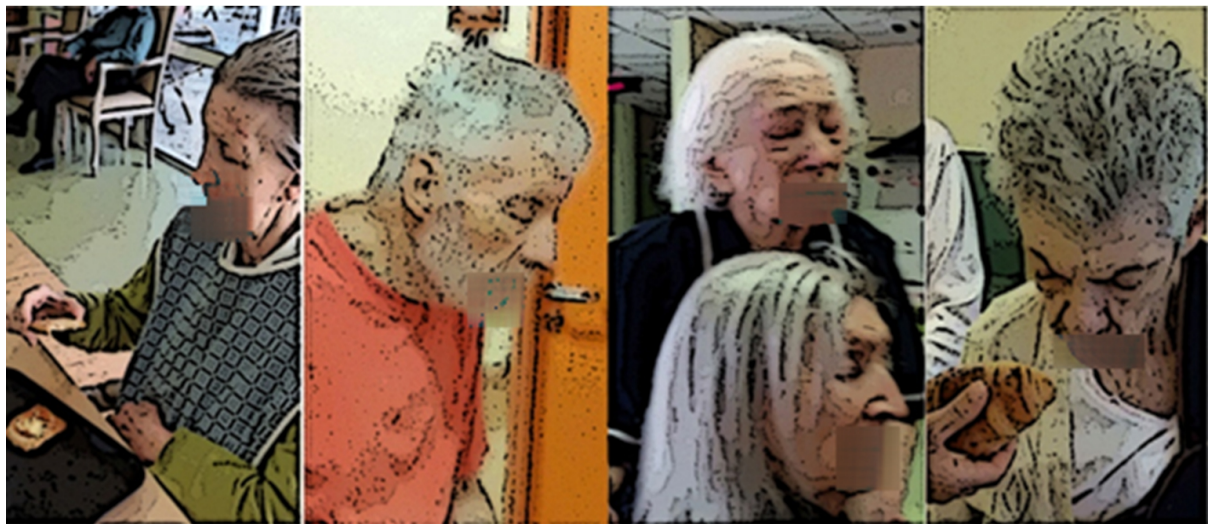

Figure 3. One of the consequences of failure of the phatic function: Regression.

an act of mutual identity giving [22]. For it to materialise, the availability of each person involved is indispensable. Alzheimer-patient identity break-down is linked to cognitive troubles and to the failure of the patient's attempts to enter into a relationship.

\section{Conclusions}

Managing the language problems of seniors with dementia means breaking out of the present over-categorising nosological framework, to enable them to attain an intersubjective dimension.

A vast area remains to be developed to really improve the assessment and management of the mental health of the elderly, so long neglected. Behind behaviour that troubles those around him, there lurks a precious sense for the senior patient with dementia which is a desire to go on living in a space of intimacy now exposed when the codes of language use no longer make it possible to maintain the necessary distance for intersubjectivity.

\section{References}

[1] Dubois, B. (2013) A new Definition for Alzheimer's Disease. Bulletin de l'Académie Nationale de Médecine, 197, 143-153; Discussion, 53-56.

[2] Thomas, P., Clement, J.P., Hazif-Thomas, C. and Leger, J.M. (2001) Family, Alzheimer's Disease and Negative Symptoms. International Journal of Geriatric Psychiatry, 16, 192-202. http://dx.doi.org/10.1002/1099-1166(200102)16:2<192::AID-GPS301>3.0.CO;2-Y

[3] Thomas, P., Montagne, B., Chantoin, S., Belmin, S., Clement, J., Hazif-Thomas, C., et al. (2001) Maladie d'Alzheimer et conscience du trouble par le malade. Conséquences pour l'aidant principal. Étude PIXEL. Revue Neurologique, 157, $4 \mathrm{~S} 13$.

[4] Holmes, D. (2014) Bruno Dubois: Transforming the Diagnosis of Alzheimer's Disease. The Lancet Neurology, 13, 541. http://dx.doi.org/10.1016/S1474-4422(14)70106-1

[5] Bird, T.D. (1993) Alzheimer Disease Overview. In: Pagon, R.A., Adam, M.P., Ardinger, H.H., Wallace, S.E., Amemiya, A., Bean, L.J.H., et al., Eds., GeneReviews ${ }^{\circledR}$, Seattle.

[6] Noble, K., Glosser, G. and Grossman, M. (2000) Oral Reading in Dementia. Brain and Language, 74, 48-69. http://dx.doi.org/10.1006/brln.2000.2330 
[7] Stilwell, B.L., Dow, R.M., Lamers, C. and Woods, R.T. (2015) Language Changes in Bilingual Individuals with Alzheimer's Disease. International Journal of Language \& Communication Disorder, 51, 113-127.

[8] Hassenstab, J., Monsell, S.E., Mock, C., Roe, C.M., Cairns, N.J., Morris, J.C., et al. (2015) Neuropsychological Markers of Cognitive Decline in Persons with Alzheimer Disease Neuropathology. Journal of Neuropathology \& Experimental Neurology, 74, 1086-1092. http://dx.doi.org/10.1097/NEN.0000000000000254

[9] Reilly, J., Rodriguez, A.D., Lamy, M. and Neils-Strunjas, J. (2010) Cognition, Language, and Clinical Pathological Features of Non-Alzheimer's Dementias: An Overview. Journal of Communication Disorders, 43, 438-452. http://dx.doi.org/10.1016/j.jcomdis.2010.04.011

[10] Jakobson, R. (1963) Linguistique et poétique, Essais de linguistique générale. Minuit (Ed) Paris.

[11] Irish, M., Kamminga, J., Addis, D.R., Crain, S., Thornton, R., Hodges, J.R., et al. (2015) “Language of the Past”Exploring Past Tense Disruption during Autobiographical Narration in Neurodegenerative Disorders. Journal of Neuropsychology.

[12] Leyton, C.E., Savage, S., Irish, M., Schubert, S., Piguet, O., Ballard, K.J., et al. (2014) Verbal Repetition in Primary Progressive Aphasia and Alzheimer's Disease. Journal of Alzheimer's Disease, 41, 575-585.

[13] Bird, H., Lambon Ralph, M.A., Patterson, K. and Hodges, J.R. (2000) The Rise and Fall of Frequency and Imageability: Noun and Verb Production in Semantic Dementia. Brain and Language, 73, 17-49. http://dx.doi.org/10.1006/brln.2000.2293

[14] Thomas, P., Ingrand, P., Lalloue, F., Hazif-Thomas, C., Billon, R., Vieban, F., et al. (2004) Reasons of Informal Caregivers for Institutionalizing Dementia Patients Previously Living at Home: The Pixel Study. International Journal of Geriatric Psychiatry, 19, 127-135. http://dx.doi.org/10.1002/gps.1039

[15] Thomas, P., Lalloue, F., Preux, P.M., Hazif-Thomas, C., Pariel, S., Inscale, R., et al. (2006) Dementia Patients Caregivers Quality of Life: The PIXEL Study. International Journal of Geriatric Psychiatry, 21, 50-56. http://dx.doi.org/10.1002/gps.1422

[16] Chantoin, S., Hazif-Thomas, C., Billon, R. and Thomas, P. (2001) Construction d'une échelle d'appréciation de la demotivation chez la personne âgée. L'Encephale, 27, 450-458.

[17] Thomas, P., Billon, R., Chaumier, J.A., Barruche, G. and Hazif-Thomas, C. (2014) Psycho-Social Hazards for Staff in Geriatrics and Geriatric Psychiatry. Open Journal of Psychiatry, 4, 91-98. http://dx.doi.org/10.4236/ojpsych.2014.42013

[18] Klimova, B., Maresova, P., Valis, M., Hort, J. and Kuca, K. (2015) Alzheimer's Disease and Language Impairments: Social Intervention and Medical Treatment. Journal of Clinical Interventions in Aging, 10, 1401-1407.

[19] Wirotius, J.-M. and Pétrissant, J.-L. (2005) Langage et discours dans la démence. Journal de Réadaptation Médicale, 25, 94-98. http://dx.doi.org/10.1016/s0242-648x(05)81185-5

[20] Coreau-Guillier, S. and Villerbu, L.-M. (2006) Facteurs psychoaffectifs de la démence; d’une hypothétique psychogenèse de la démence. Revue des théories actuelles. NPG, 6, 29-35.

[21] Simeone, I. (1990) Les aspects psychodynamiques des troubles de comportement chez le sujet sénescent et leur approche psychodynamique. Santé mentale au Québec, 15, 33-46. http://dx.doi.org/10.7202/031561ar

[22] Buber, M. (1980) Je et tu. Aubier Bibliothèque philosophique Paris.

\section{Submit or recommend next manuscript to SCIRP and we will provide best service for you:}

Accepting pre-submission inquiries through Email, Facebook, Linkedin, Twitter, etc

A wide selection of journals (inclusive of 9 subjects, more than 200 journals)

Providing a 24-hour high-quality service

User-friendly online submission system

Fair and swift peer-review system

Efficient typesetting and proofreading procedure

Display of the result of downloads and visits, as well as the number of cited articles

Maximum dissemination of your research work

Submit your manuscript at: http://papersubmission.scirp.org/ 